\title{
Natural cross-pollination in roselle, Hibiscus sabdariffa L. (Malvaceae)
}

\author{
K.R. Vaidya
}

\begin{abstract}
Two local varieties of roselle (Hibiscus sabdariffa L.), Jamaican Green and Jamaican Red, were grown to determine the amount of natural cross-pollination. Two planting arrangements (alternating rows; alternating individuals in a row) and two planting dates, a month apart, were used for the outcrossing experiments. Stem pigmentation, red (R-) vs. green (rr), was used as a genetic marker in the estimation of outcrossing. Homozygous dominant and recessive genotypes of Jamaican Red and Jamaican Green, respectively, were grown in both of the planting arrangements and dates. Seeds from open-pollinated capsules of randomly selected Jamaican Green plants were planted to score the frequency of cross-pollination. Estimates of natural cross-pollination ranged from $0.20 \pm 0.09 \%$ to $0.68 \pm$ $0.34 \%$. Roselle outcrosses at a low rate in Jamaica.
\end{abstract}

\section{INTRODUCTION}

Roselle (Hibiscus sabdariffa L.), an annual or biennial plant belonging to the family Malvaceae, is cultivated in tropical and subtropical regions for stem fibers, paper pulp or edible calyces, leaves and seeds (Wilson and Menzel, 1964; Adamson and O'Bryan, 1981). This species was probably brought to the western hemisphere by slaves from Africa and its use in Jamaica was noted as early as 1707 (Crane, 1949). Roselle is an important crop in Jamaica, where traditionally the fleshy calyces are used for the preparation of a drink during the Christmas season. The plant, known locally as sorrel, is exported from Jamaica mainly to West Indian communities in the UK and North America.

Knowledge of the outcrossing rate of a crop species in a specific environment is important when choosing a breeding procedure for crop improvement, germplasm maintenance, and commercial seed production. Howard and Howard (1911) reported no natural outcrossing in roselle in India. On two occasions, these workers found progenies of interlaced plants from different varieties to be true-breeding and uniform, and attributed the absence of natural outcrossing in this species to (1) the short period during which the flowers were open, (2) the presence of stigma tips which were flush with the opening of the staminal column, and (3) the fact that stigmas did not grow in air and closing of the flowers precluded further genetic exchange. Sanyal and Dutta (1954), on the other hand, reported $0.23 \%$ natural outcrossing in roselle in India.

Only two varieties of roselle, Jamaican Red and Jamaican Green, are grown in Jamaica. Prior to the initiation of a breeding program for roselle, the extent of outcrossing in this species in the western hemisphere was unknown. In addition, there was no information on pos- sible natural cross-pollination between local Jamaican varieties grown adjacent to one another in small plots, although foraging by honey bees and other insects had been observed in fields planted with roselle. Young (1995) reported an outcrossing rate of $<1 \%$ in roselle based on experiments conducted adjacent to breeding nurseries. However, this rate may have been influenced by the lack of isolation. A study was conducted to determine the rate of natural cross-pollination in Jamaican varieties of roselle in isolation, under field conditions where honey bees and other insects were present.

\section{MATERIAL AND METHODS}

Two varieties of roselle, Jamaican Red and Jamaican Green, were found to be true-breeding in previous years of the breeding program and were considered to be homozygous. These varieties have synchronous flowering and were used in field plantings. Two planting arrangements were used during the first and second planting (Figure 1).

\begin{tabular}{|c|c|c|c|c|c|c|c|c|c|c|c|c|c|c|c|}
\hline \multicolumn{16}{|c|}{ Planting arrangements } \\
\hline \multicolumn{8}{|c|}{ A } & \multicolumn{8}{|c|}{ B } \\
\hline $\mathrm{X}$ & $\mathrm{X}$ & $\mathrm{X}$ & $\mathrm{X}$ & $\mathrm{X}$ & $\mathrm{X}$ & $\mathrm{X}$ & $\mathrm{X}$ & $\mathrm{X}$ & 0 & $\mathrm{X}$ & 0 & $\mathrm{x}$ & 0 & $\mathrm{X}$ & 0 \\
\hline 0 & 0 & 0 & 0 & 0 & 0 & 0 & 0 & 0 & $\mathrm{X}$ & 0 & $x$ & 0 & $\mathrm{x}$ & 0 & $\mathrm{x}$ \\
\hline $\mathrm{x}$ & $\mathrm{x}$ & $\mathrm{x}$ & $\mathrm{x}$ & $\mathrm{x}$ & $\mathrm{x}$ & $\mathrm{x}$ & $\mathrm{x}$ & $\mathrm{x}$ & 0 & $\mathrm{x}$ & 0 & $\mathrm{x}$ & 0 & $\mathrm{x}$ & 0 \\
\hline 0 & 0 & 0 & 0 & 0 & 0 & 0 & 0 & 0 & $\mathrm{x}$ & 0 & $\mathrm{x}$ & 0 & $\mathrm{x}$ & 0 & $\mathrm{x}$ \\
\hline
\end{tabular}

Figure 1 - Planting arrangements used during the first and second planting to estimate outcrossing rate. 
Table I - Estimates of natural cross-pollination in Hibiscus sabdariffa based on plants produced from seeds of homozygous recessive (green) genotype.

\begin{tabular}{|lccccc|}
\hline Planting date & Planting & No. of progenies & \multicolumn{2}{c|}{ No. of plants with } & Outcrossing \\
\cline { 4 - 5 } & arrangement & evaluated & Green stems & Red stems & \\
\hline October 7, 1997 & $\mathrm{A}^{*}$ & 20 & 5097 & 5 & $0.20 \pm 0.09$ \\
October 7, 1997 & $\mathrm{B}$ & 12 & 1854 & 4 & $0.43 \pm 0.21$ \\
November 4, 1997 & $\mathrm{A}$ & 20 & 6513 & 9 & $0.27 \pm 0.09$ \\
November 4, 1997 & $\mathrm{B}$ & 11 & 1176 & 4 & $0.68 \pm 0.34$ \\
\hline
\end{tabular}

${ }^{*} \mathrm{~A}=$ Alternating rows; $\mathrm{B}=$ alternating individuals in a row.

The outcrossing experiments were planted on October 7 and November 4, 1997, for the first and second planting, respectively. The distance between rows and plants within rows was $30 \mathrm{~cm}$ in all of these experiments. Each row of the outcrossing plots was $4.5 \mathrm{~m}$ long. Equal numbers of Jamaican Green and Jamaican Red plants were maintained in each of the outcrossing plots. Stem pigmentation character was used as a genetic marker. Red pigmentation is controlled by a dominant allele and the green by a recessive allele (Chakravarty and Basu, 1972).

Open pollinated capsules from randomly selected plants of the Jamaican Green genotype were harvested and each plant threshed separately. In the off-season, individual plants in the progeny rows of Jamaican Green were scored either as selfs or outcrosses based on the number of recessive and dominant phenotypes. The mean number of plants per progeny row from the first planting was 225 and 155 for arrangements A and B, respectively. However, from the second planting, the mean number of plants per progeny row was 326 and 107 for arrangements A and B, respectively. The percentage of outcrossing was calculated as $t$ $=\mathrm{H} / \mathrm{p} \times 100$, where $\mathrm{p}$ is the frequency of the dominant allele in the pollen pool; $\mathrm{H}$, the frequency of heterozygotes (observed outcrossing), is equal to $a /(a+b)$, where $a$ is the number of heterozygotes and $b$, the number of recessive homozygotes in the progeny of the recessive genotype (Jain, 1979). The frequency of heterozygotes was divided by the pollen allelic frequency $(\mathrm{p}=0.5)$ to adjust for intragenotypic outcrossing.

\section{RESULTS AND DISCUSSION}

The estimates of natural outcrossing rates in roselle ranged from 0.20 to $0.68 \%$ (Table I), which means that in Jamaica roselle outcrosses at a low rate. The estimates of natural cross-pollination were comparable to those reported by Sanyal and Dutta (1954) and Young (1995). It is not known whether Howard and Howard (1911) and Sanyal and Dutta (1954) used the same genotypes in the estimation of outcrossing rate in roselle. The differences in the estimates of natural cross-pollination when compared to roselle from India presumably reflect the divergent genotypes. Variation in the rate of natural outcrossing among genotypes has beeen reported for the common bean (Nagata and Bassett, 1985).

The relative contribution of pollination by wind and insects and of direct mechanical contact among flowers to outcrossing among different roselle genotypes is unknown. If natural cross-pollination depends largely upon insect transfer of pollen, then it is possible that flower color could affect insect activity and the natural outcrossing rate. Thus, in an experimental population of cowpea containing equal frequencies of two morphs, purple and white flowers, Leleji (1973) found that bumble bees preferred purple flowers over white ones by a ratio of $3: 1$. Of the two roselle genotypes used in this study, flowers of the Jamaican Red genotype have a very prominent crimson color at the base of the petals, whereas those of the Jamaican Green genotype do not. However, the influence of flower color on the outcrossing rate in this species is unknown. The planting arrangement of the genotypes did seem to indicate different rate of natural outcrossing in roselle (Table I).

Since natural cross-pollination was observed in roselle, selfing must be done to maintain the genetic purity of the diverse germplasm accessions which would be in close proximity in a breeding nursery. For genetic improvement, variety multiplication and seed certification, roselle could be cultivated in a manner similar to other self-pollinated crops.

\section{ACKNOWLEDGMENTS}

The author thanks Mr. L. Johnson for his help in the fieldwork and Miss K. Anderson for typing the manuscript.

\section{RESUMO}

Duas variedades locais de "roselle" (Hibiscus sabdariffa L.), Jamaican Green e Jamaican Red, foram cultivadas para se determinar a quantidade de polinização cruzada natural. Dois arranjos de plantio (fileiras alternadas e indivíduos alternados em uma fileira) e duas datas de plantio, separadas por um mês, foram usadas para os experimentos de exocruzamento. A pigmentação do caule, vermelha (R-) vs. verde (rr), foi usada como um marcador genético na estimativa do exocruzamento. Genótipos homozigotos dominantes e recessivos de Jamaican Red e Jamaican 
Green, respectivamente, foram cultivados nos dois arranjos de plantio e em ambas as datas. Sementes de cápsula de polinização aberta de plantas de Jamaican Green selecionadas ao acaso foram plantadas para se determinar a freqüência de polinização cruzada. As estimativas de polinização cruzada natural variaram de $0,20 \pm 0,09 \%$ a $0,68 \pm 0,34 \%$. A taxa de exocruzamento de "roselle" na Jamaica é muito baixa.

\section{REFERENCES}

Adamson, W.C. and O'Bryan, J.E. (1981). Inheritance of photosensitivity in roselle, Hibiscus sabdariffa. J. Hered. 72: 443-444.

Chakravarty, K. and Basu, N.C. (1972). The anthocyanin pigmentation pattern in Hibiscus sabdariffa L. and its mode of inheritance, with special reference to the variation intermedius. Genetica $43: 366-374$.

Crane, J.C. (1949). Roselle - a potentially important plant fiber. Econ. Bot. 3 : 89-103.
Howard, A. and Howard, G.L.C. (1911). Studies in Indian fibre plants. No. 2. On some new varieties of Hibiscus cannabinus L. and Hibiscus sabdariffa L. Indian Dep. Agric., Mem. Bot. Serv. 4: 9-36.

Jain, S.K. (1979). Estimation of outcrossing rates: some alternative procedures. Crop Sci. 19: 23-26.

Leleji, O.I. (1973). Apparent preference by bees for different flower colors in cowpeas (Vigna sinensis (L.) Savi ex Hasak.). Euphytica 22: 150-153.

Nagata, R.T. and Bassett, M.J. (1985). A dwarf outcrossing mutant in common bean. Crop Sci. 25: 949-954.

Sanyal, P. and Dutta, A.N. (1954). Natural crossing in Hibiscus sabdariffa. Sci. Cult. 19: 407-408

Wilson, F.D. and Menzel, M.M. (1964). Kenaf (Hibiscus cannabinus), roselle (Hibiscus sabdariffa). Econ. Bot. 18: 80-91.

Young, M.M. (1995). Ethylmethane sulphonate induced mutations and other studies on Jamaican sorrel (Hibiscus sabdariffa var. sabdariffa). M. Phil. thesis, University of the West Indies, Mona, Kingston 7, Jamaica (W.I.).

(Received May 3, 1999) 
